\title{
Position of Water Elements as an Urban Furniture
}

\author{
Aysel Tarım
}

\begin{abstract}
Water and water elements as the main materials of the organic architecture which has become a new style in recent years increased its significance day by day in urban design concept.

People have always benefited from water structures since the ancient times. While the fountains had been used as the water elements in urban furniture previously, decorative pools, waterfalls, water channels, water walls, ponds and many similar water structures are still used today as an integral part of cities. The water structures which have reached today from the past by meeting some needs of people are beatifying the environment we live in different and various styles day by day.

This study aims to identify different types of water elements which have a significant position in common use spaces of urban people during current years in which urban transformation and innovation works become important, and illustrate forms of use of these elements, then refer and share the technical characteristics such as design and maintenance. The criteria such as function, aesthetic, form, material, color, pattern and perceptibility which may create distinctness in design of urban furniture are addressed and today's urban furniture is evaluated with water elements design examples.

In conclusion, distinctive and creative water elements urban furniture designs improve both quality of usage and visual quality in spaces they are located and may positively affect the urban identity and psychological status of users.
\end{abstract}

Keywords - water elements, urban furniture, fountains.

\section{INTRODUCTION}

Water is one of the components which comes into prominence with its aesthetic and functional characteristics and is frequently used in designs in urban outdoor and green areas. Having various functional characteristics such as being the focus point, recreation, circulation control, visual and audio shielding and cooling etc., water is used in design. Water elements create tranquility and excitement depending on its sound and intensity and contribute in users in aesthetic sense. Additionally, some aesthetic characteristics of water such as appearance, color etc. have some relaxing and refreshing effects on people. Water is used as an indispensible component of landscape in urban green areas and adds motion in the environment it exists.

City is a whole composed of different spaces. The outfit components designed and individuate in a space should not only arrange the space but should also create a systematic for outfit areas in the city. The meaning and role of public outdoor

Aysel Tarım, Mimar Sinan Fine Arts University, Turkey spaces that are influential on city quality and identity depend on the level of organization, design and detail they have [1].

Being a part of the identity of cities, structural elements take shape as a result of social and cultural characteristics and natural factors. Landscape architects utilize not only plants as living materials but also nonliving materials to improve quality of visual environment and create more worth living spaces in cities. Aesthetic perception varies from person to person and takes a role in formation of artificial elements which constitute a part of city identity with culture affinity [2].

Both single structures and the atmosphere formed by togetherness of structures and outdoor green areas should have some aesthetic characters which satisfy psychological and intellectual requirements of people other than just having functionality that satisfies the biological needs [3].

Urban furniture has a highly significant role in terms of simplifying urban identity and social life.

Urban furniture is authentic design products which support and strengthen our surrounding streets, avenues, roads, car parks, terrace, pedestrian walks and squares as well as the functions such as sitting, sheltering, protection, enclosure, consultation, illumination, transportation, communication, playing and sports which take place in public o private usage areas, make social life easier, gain admiration and support of users and are influential in formation of functional, safe and healthy atmospheres in indoor and outdoor spaces of urban and rural areas [4].

\section{CLASSIFICATION AND DESIGN PRINCIPLES OF WATER ELEMENTS}

We may group water components as fountains and other water elements (decorative pools, ponds, waterfalls, water channels, water walls, water gardens and water play grounds) in urban furniture.

\section{I Fountains}

Fountains are the most common examples of water architecture. There are three types of fountains. Rising and falling down sprinklers or combination of both.

They become a focus on the place they exist. "Fountain" (Çeşme in Turkish) is derive from the word "çeşm" which means "eye" in Persian language. Calling the springs, founts and bodies as "çeşm" has led to call small structures from which this water flows as çeşme in Turkish (fountain) [5].

Fountain facets which are mostly encircled with flat edges and cornices have flat solid designs with simple appearance. 
Street fountains display various designs with single, two or three facets. The existing fountains include examples which are placed on the surface of an individual wall or the corner on which two streets cross. Most of the fountains have a water reservoir.

Various construction materials such as stone, marble, brick, tile, adobe brick, plaster, mortar, wood, iron and lead have been used in fountain structures in the past. Today, mostly iron, stainless steel, brass and some different metals are being used. There are different designs with and without handle etc. The hollow part made of glazed tile or other materials on which the waters flowing from fountain taps is called as tray or flume.

Fountains are ideal for use in small spaces. They are constructed centrally as an individual structure or as attached to any architectural work. Each nation has fountains specific to its own culture [6].

\section{II Other Water Components}

Water component is an indoor or outdoor decor including water [7]. It ranges from a small tabletop sprinkler or water ponds through a flowerpot to a large commercial lake or retainment pools.

\section{II.I Decorative Pools, Flowerpot Water Gardens and Sprinkler Landscape}

Small cans are usually used to put water on backyards or veranda. However, today we frequently see these cans on doorsteps to welcome guests, in park and garden decors, reception and resting areas of public buildings. This landscape does not only appeal to the eye but its characteristics of eliminating stress are the most crucial characteristics which help children to learn about nature and relaxing people.

Sprinkler landscape is composed of small decorative water forms such as tabletop fountains, flowerpot water gardens, single fountains, sprinkler forms, land pieces settled on water and fountains included in a ground depot.
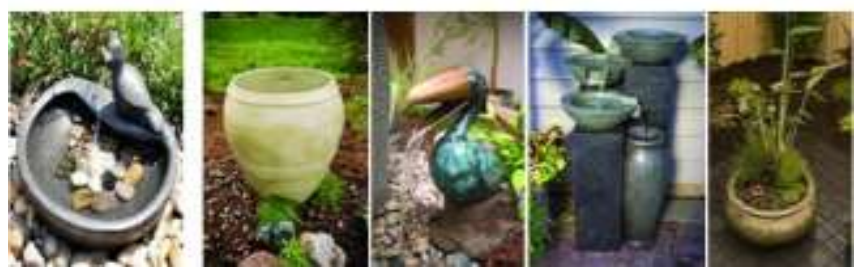

Fig. 1: Different Flowerpot, Decorative Pools and Sprinkler Applications

Example for flowerpot water gardens and sprinkler objects are given above.

\section{II.II Waterfalls}

Waterfalls includes a stream or water fall there is no pond and water is circulating. They are the structures by which you can enjoy sound and appearance of flowing water without need for maintenance of a pond.

Their usage has increased generally in large parks.

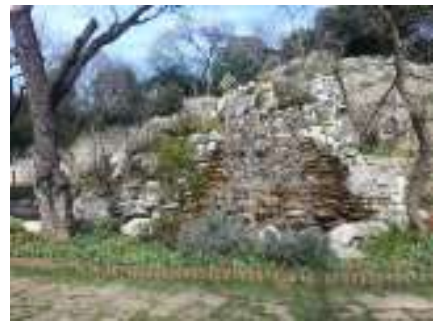

Fig. 2: Üsküdar Fethipaşa Waterfalls /İstanbul

\section{II.III Biological Pools}

Biological pools are established on a system with self cleaning feature. They have an appearance like a natural pond that cleans itself and requires less maintenance by this way.

Cleaned water and plant areas exist together in the biological pools which have essentially the same principles with a concentric system swimming pool. Water purification is performed without using any chemical substance by means of water plants and useful microorganism. They are mostly applied in boskets and large parks.
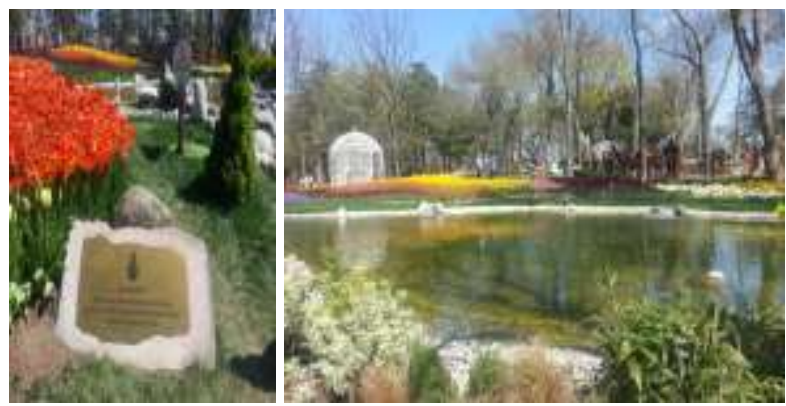

Fig. 3: Emirgan Grove Biological Polls / İstanbul

\section{II.II.IV Water Plays}

These urban components which have been increasingly used in recent years gained a significant position in a short time. They may be applied both in public parks and pedestrianized streets.

It takes attention that the water jet sprinkler system which creates the effect of travel of water particles from some place to another almost with jet velocity is on the ground level. They are used mostly by children for playing and cooling during summer time.
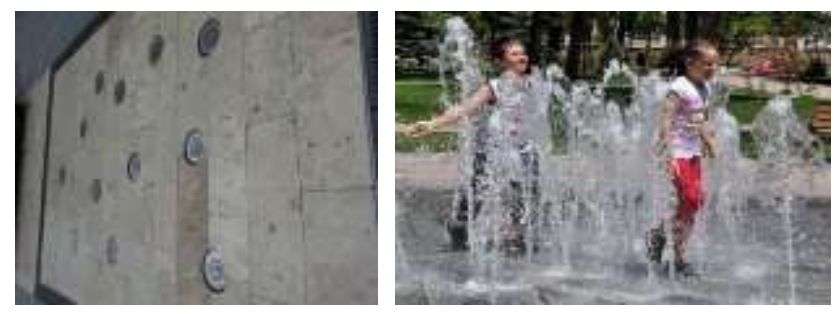

Fig. 4: Water Plays Cennet District / İstanbul 


\section{II.II.V Water Channels}

Water channels is mostly used for transmitting back the water flowing from decorative pools and connecting with other pools.
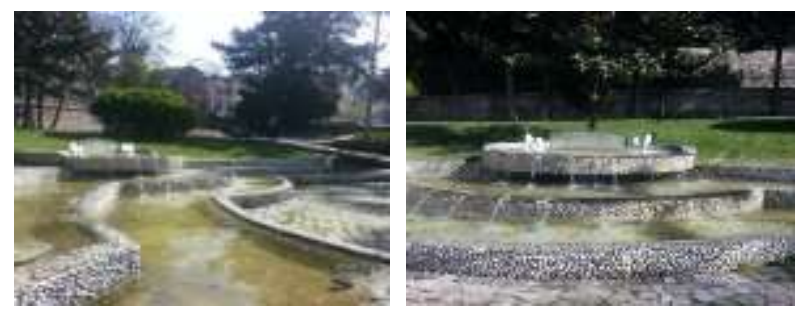

Fig. 5: Water Channels Üsküdar Fethipaşa Grove / İstanbul

\section{II.II.VI Water Walls}

Water walls also form a useful decoration option that is beneficial for human health in addition to their visual and audio effect. It has been known since ancient times that flow, appearance and sound of water positively affects human psychology.

On the other hand, they have the influence of transforming positive ions into negative ions existing in the environment during the flow of water over water walls in addition to such effects.

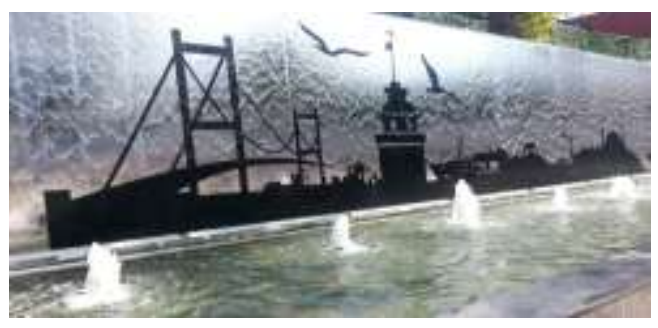

Fig. 6: Water Walls Üsküdar Square / İstanbul

Water walls have started to be used in recreation areas, welcome centers and squares of cities in recent years. As is seen in Figure 6, some components reflecting the city identity are also included in this design.

\section{II.II.VII Water Gardens}

Water plants are grown in water gardens which are similar to decorative pools. Water garden is one of the most ideal design components which may be preferred in planning of gardens. It is possible to improve a space to a moving level by applying some designs to be selected according to every style of park.

Plants will gain richness and create a more peaceful environment for people by means of the perspective and reflections brought in by water.

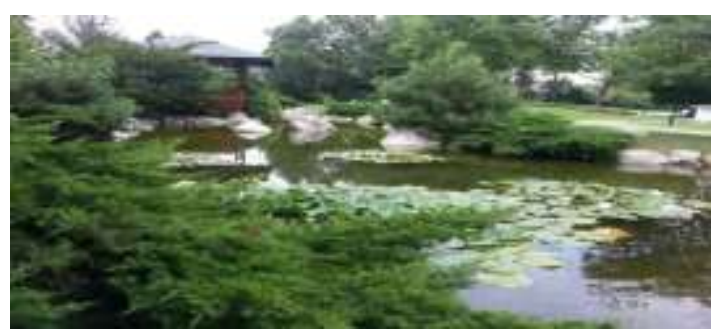

Fig. 7: Water Gardens Japanese Garden Baltalimanı / İstanbul

Water is the most important garden material included in main planning of landscape architects currently by pushing the factors such as garden plants and grass which requires intensive gardening work into the background. The important thing here is to apply the water area you wish to create such as decorative pool, pond, flowing stream, sprinklers, fishing pool on the right point of a park or space by means of correct choice and planning.

Choosing slightly shadow and sun-drenched areas is important because shadow areas would rapidly green water and cause bacteria. The areas below plants which drop flowers and leaves should not be preferred.

\section{II.II.VIII Sprinkler Decorative Pools}

Sprinkler decorative pools are among the most common water elements. Special sprinkler and water show models are designed by using different water figures at squares, junctions, building front, park and garden pools.

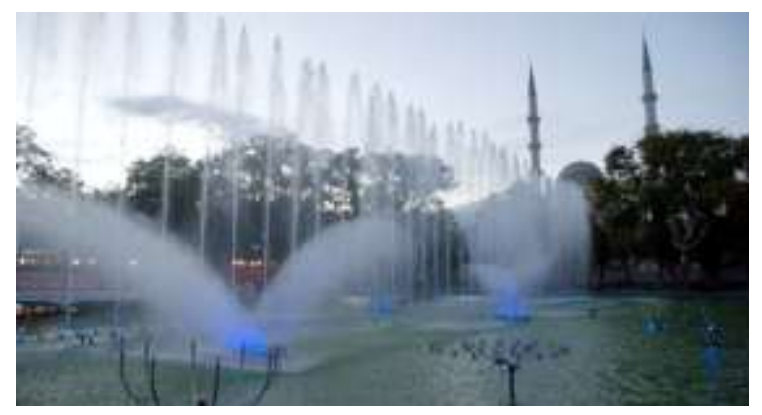

Fig. 8: Water Sprinkler Decorative Pools /Turkey 


\section{EXAMPLES From THE WORLD For WATER ELEMENTS DESIGN}

When the water components designed in outdoor spaces are examined, very different characteristics are observed. There are different kinds of water components located at parks for different events, children play grounds, roadsides. Water component is used to bring motion in empty spaces while planning outdoor areas. Designers have started to use water components increasingly by considering psychological needs of people.

Special sprinkler and water show models are designed by using different water figures at junctions, building front, park and garden pools.

Any product suggested at design process must serve for a certain objective, should be functional by emerging as a result of a conscious thought, and should carry a characteristic specific to itself out of the ordinary, unique and different from previously applied designs.

Examples;
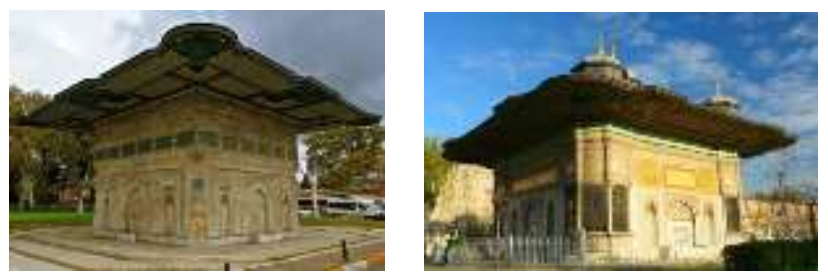

Fig. 9: Tophane Fountain İstanbul Fig. 10: 111. Ahmet Fountain
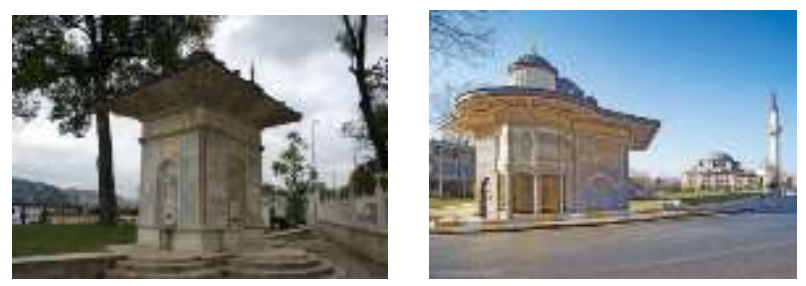

Fig. 11 Göksu Fountain İstanbul Fig.12: Saliha Sultan Fountain

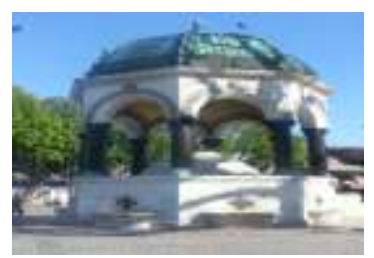

Fig.13 Sultanahmet Alman

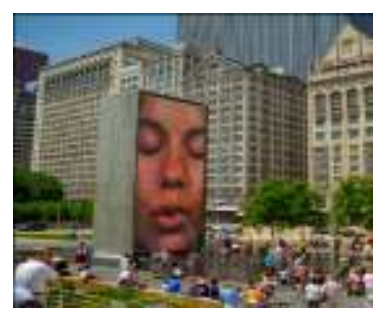

Fig.15 Milenium Park Fountain USA Fig.16: Swann Fountain
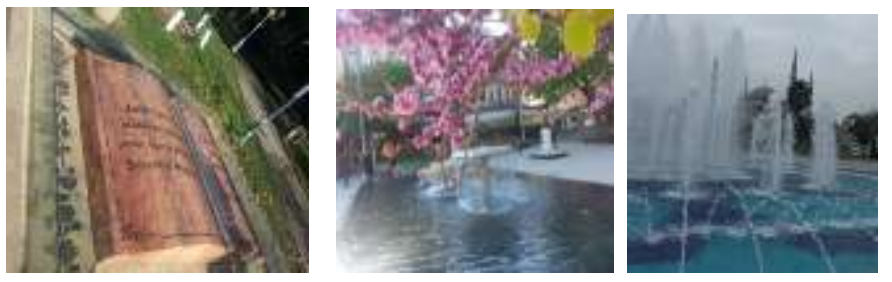

Fig.17:Gülhane Water Element Fig.18-19: Sultanahmet Square Pond / İstanbul
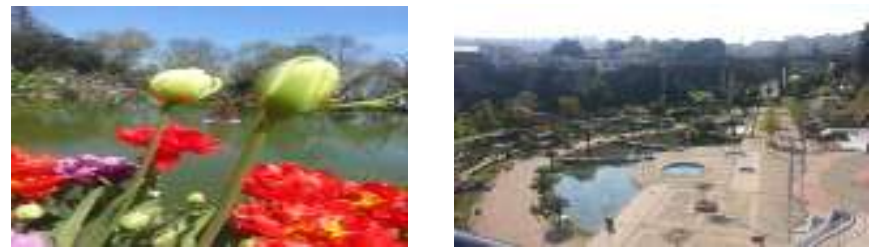

Fig.20: Biological Pools Emirgan/İstanbul Fig.21: Trabzon Zağanos Pond / Trabzon
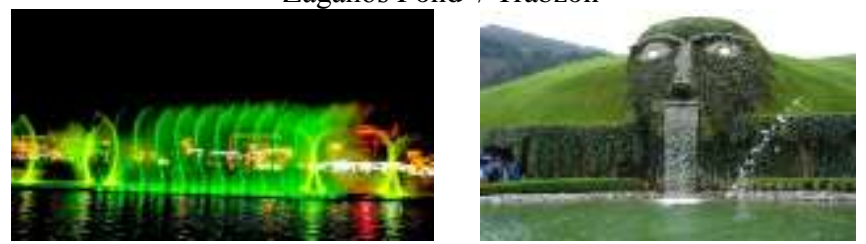

Fig.22: Denizli İncili Pınar Park, Fig.23:Sawarovski Face, Fountain / Austia
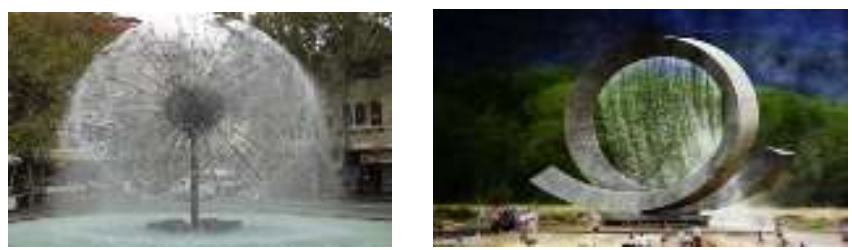

Fig.24: The El Alamein Fointain in Sydney, Fig.25: Julie Penrose Fountain Colorado Springs, USA,
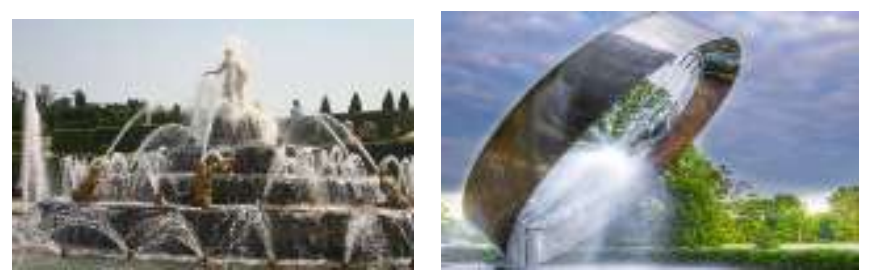

Fig.26:Versilles Palace Garden France, Fig.27: Fountain, Ohio USA
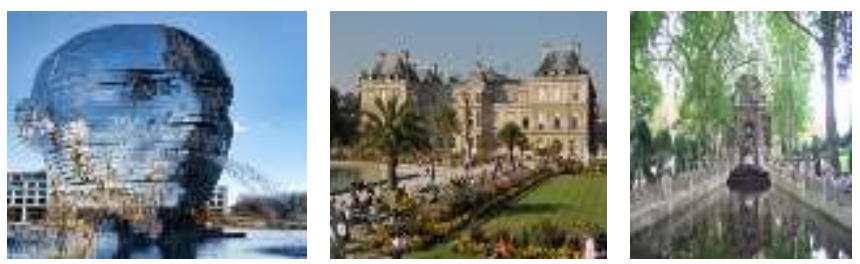

Fig.28: Metalmorphosis Charlotte North Carolina USA, Fig.29-30: France Luxembourg Garden and Water Park 

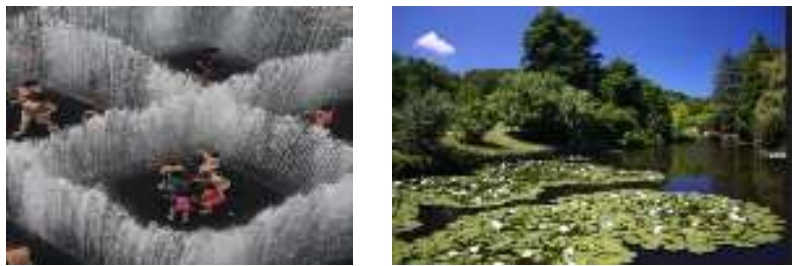

Fig.31: Londra Water Walls Fig.32: Atatürk Arboretumu Biological Pool/ İstanbul
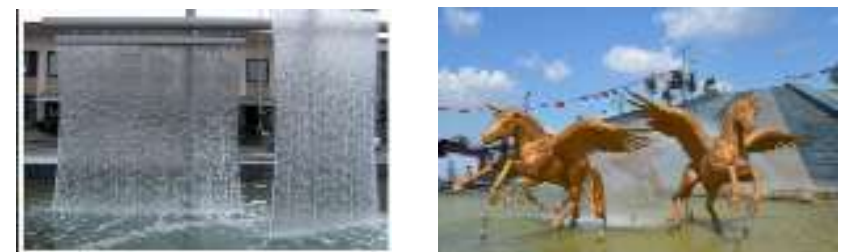

Fig.33: Water Curtain, Fig.34: Bakırköy Botani Park İstanbul
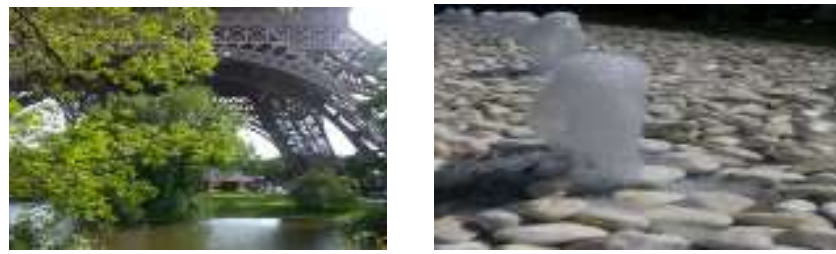

Fig.35: Paris Eiffel Tower Biologica Pool France, Fig.36: Emirgan Korusu Water Element / İstanbul İstanbul

\section{CONCLUSION}

Water is the most popular breakpoint that moves us away from the real world and sets free from daily fatigue duties. Water components provide a relaxing view and sound that makes us rest by moving away from intensive stress of a day. Environmental sustainability is centric in today's world. Water has a significant role as the most fabulous resource of the world. An ecosystem pond ensures its continuity with a small maintenance.

It requires attention that water components should form a wholeness and compliance with the characteristics of space and environment. Water components should be designed by considering the characteristics of a unit they exist in urban outdoor green areas (streets, squares, city park etc.).

Climatic characteristics of an area being designed should be considered while deciding the form of using water component in a design. Water components should take place particularly in landscape designs performed in warm climate regions.

By considering all people benefit from water components (children, disabled, elderly), special care should be taken to ensure that they have an appropriate depth according to desired aesthetic and functional effects when safety criteria are considered.

The effect of water components on people and expectations of people from water components are different according to their socio-economic characteristics. Therefore, socioeconomic characteristics of the intended target user group who use or is predicted to use the areas having the water component design.

When considering the characteristics of being perceived of water components according to fife sense organs of a healthy person depending on distance, the feature firstly perceived is the appearance. So, special care should taken to ensure that visual quality of water components is good while performing the design.

City parks are the important prestige areas of cities. Water components used in city parks are also among important elements of the parks.

The importance of water in human life is undoubtedly countless. Authentic urban furniture designs not only beautify the spaces they are located but also positively affect psychological status of users.

\section{REFERENCES}

[1] Moughtin, C. 1999. Urban Design: Street and Square. Architectural Press, 238 .

[2] Özer, S., Aklıbaşında, M., Zengin, M. 2010. Erzurum Kenti Örneğinde Kullanılan Kuşatma Elemanlarının Kent İmajı Üzerindeki Etkileri. Tekirdağ Ziraat Fakültesi Dergisi, 7(2), 123-130.

[3] Erdoğan, E. 2006. Çevre ve Kent Estetiği. ZKÜ Bartın Orman Fakültesi Dergisi, Cilt 8, Say1: 9, 68-77.

[4] Başal, M. 2002. Donatı Elemanları, Basılmamış Ders Notları. Ankara Üniversitesi Ziraat Fakültesi Peyzaj Mimarlığı Bölümü, Ankara.

[5] www.abihayatsergisi.com/?portfolio=denem/cesmelervesebiller

[6] http://cesme.nedir.com/\#ixzz3XBJuS3j4

[7] http://www.ekosistemgoletleri.com/su-ogesi-nedir.html 